\title{
Erratum to: Antigen production using heterologous expression of dengue virus-2 non structural protein 1 (NS1) in Nicotiana tabacum (Havana) for immunodiagnostic purposes
}

Marilane O. F. Amaro ${ }^{1}$ - Mariana F. Xisto ${ }^{1}$ - Ana Carolina F. Dias ${ }^{1}$. Alice F. Versiani ${ }^{1,2,3}$ - Silvia A. Cardoso ${ }^{1}$ - Wagner C. Otoni ${ }^{2}$. Cynthia C. da Silva ${ }^{3}$ - Sérgio O. De Paula ${ }^{1}$

\section{Erratum to: Plant Cell Rep (2015) 34:919-928 DOI 10.1007/s00299-015-1753-5}

Unfortunately, Figure 1B of the original article shows the wrong gel. The correct figure is given below.

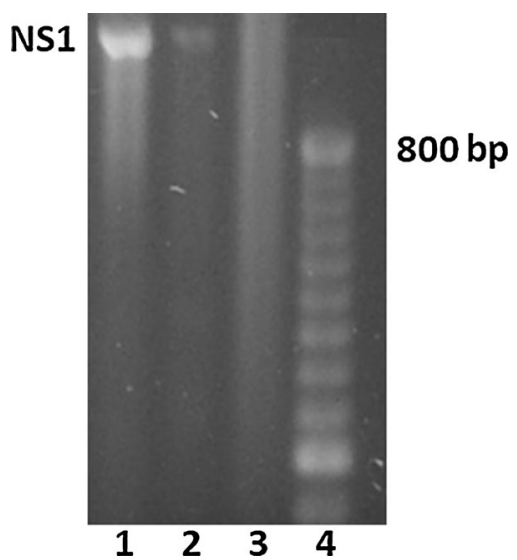

Fig. 1B Construction of recombinant Agrobacterium tumefaciens lineage for expression of dengue virus-2 NS1 gene. b Amplification of NS1 gene in Agrobacterium tumefaciens transformed with pCAMBIA 3301/NS1 plasmid. 1 and 2 representative samples of transformed A. tumefaciens; 3 negative control (representative untransformed A. tumefaciens); 4100 bp DNA marker

The online version of the original article can be found under doi:10.1007/s00299-015-1753-5.

Sérgio O. De Paula

depaula@ufv.br

1 Laboratory of Molecular Immunovirology, Department of General Biology, Federal University of Viçosa,

Av. PH Rolfs, s/n Campus Universitário, Viçosa, MG CEP 36570-000, Brazil

2 Department of Vegetal Biology, Federal University of Viçosa, Viçosa, MG, Brazil

3 Department of Microbiology, Federal University of Viçosa, Viçosa, MG, Brazil 